\title{
Contextual Effect of Community Health Center on Visual Inspection Acetic Acid Uptake in Magelang, Central Java: A Multilevel Analysis
}

\author{
Herlina Ika Martaningrum(1), Uki Retno Budihastuti²), Bhisma Murti') \\ 1)Masters Program in Public Health, Universitas Sebelas Maret \\ ${ }^{2)}$ Department of Obstetrics and Gynecology, Dr. Moewardi Hospital, Surakarta
}

Background: Cervical cancer is a major problem in women's. Cervical cancer can be prevented by early examinations i.e. visual inspection acetic acid (VIA). This study aimed to analyze contextual effect of community health center on VIA uptake in Magelang, Central Java.

Subjects and Method: This was analytic observational study with cross sectional design. The study was conducted at 25 community health centers in Magelang, Central Java, from September to October 2019. A total sample of 200 women aged 30 to 50 years was selected randomly. The dependent variable was VIA uptake. The independent variables were knowledge, observational learning, behavioral reinforcement, cues for action, access to information, family support, attitude, self-efficacy, outcome expectation, and contextual factor of community health center. The data were collected by questionnaire and analyzed by a multilevel multiple logistic regression run on Stata 13.

Results: VIA uptake increased with good knowledge $(b=4.02 ; 95 \% \mathrm{CI}=0.61$ to $7.42 ; \mathrm{p}=0.021)$, observational learning $(b=2.28 ; 95 \% \mathrm{CI}=-0.35$ to $4.93 ; \mathrm{p}=0.090$ ), strong behavioral reinforcement $(b=4.11 ; 95 \% \mathrm{CI}=0.82$ to $7.40 ; \mathrm{p}=0.014)$, strong cues to action $(b=5.36 ; 95 \% \mathrm{CI}=0.65$ to
10.07; $\mathrm{p}=0.026)$, good access to information $(\mathrm{b}=$ $3.71 ; 95 \% \mathrm{CI}=0.42$ to $7.01 ; \mathrm{p}=0.027)$, strong family support $(b=4.23 ; 95 \% \mathrm{CI}=0.21$ to 8.25 ; $\mathrm{p}=0.039)$, positive attitude $(\mathrm{b}=3.29 ; 95 \% \mathrm{CI}=-$ 0.23 to $6.81 ; p=0.067)$, strong self-efficacy $(b=$ $2.94 ; 95 \% \mathrm{CI}=0.10$ to $5.78 ; \mathrm{p}=0.042)$, and strong outcome expectation $(\mathrm{b}=3.39 ; 95 \% \mathrm{CI}=$ 0.35 to $6.44 ; \mathrm{p}=0.029)$. Community health center had strong contextual effect on VIA uptake with intra-class correlation (ICC) $=23 \%$.

Conclusion: VIA uptake increases with good knowledge, observational learning, strong behavioral reinforcement, strong cues to action, good access to information, strong family support, positive attitude, strong self-efficacy, and strong outcome expectation. Community health center has strong contextual effect on VIA uptake.

Keywords: visual inspection acetic acid, social cognitive theory, multilevel analysis

\section{Correspondence:}

Herlina Ika Martaningrum, Masters Program in Public Health, Universitas Sebelas Maret. Jl. Ir. Sutami 36A, Surakarta 57126, Central Java, Indonesia. Email: herlinaika21@gmail.com. Mobile: 085643528156

\section{Cite this as:}

Martaningrum HI, Budihastuti UR, Murti B (2020). Contextual Effect of Community Health Center on Visual Inspection Acetic Acid Uptake in Magelang, Central Java: A Multilevel Analysis. J Matern Child Health. 5(2): 129-140. https://doi.org/10.26911/thejmch.2020.05.02.02

cc (i) (-) Journal of Maternal and Child Health is licensed under a Creative Commons Attribution-Non Commercial-Share Alike 4.o International License.

\section{BACKGROUND}

Cancer places the second rank among causes of death in the world, and is responsible for 9.6 million deaths in 2018 (WHO, 2018). Cervical cancer is a major problem in women's health in the world, especially in deve- loping countries that have limited resources such as Indonesia (Momenimovahed and Salehiniya, 2017).

The incidence of cervical cancer for women in Indonesia is 23.4 per 100,000 population with an average death of 13.9 per 
100,000 population (Ministry of Health, 2019). Most cervical cancer cases can be prevented by implementing a preventive program (Momenimovahed and Salehiniya, 2017). WHO recommends an alternative approach for countries that are developing the concept of down staging for cervical cancer, one of which is the VIA method. This method uses easy techniques, low cost, and high sensitivity (Shaheen et al., 2014).

Women's awareness of screening is still considered poor (Health Office of Magelang District, 2018). Good health facilities and services that are spread in various regions are considered not comparable to women's awareness (Central Java Health Office, 2018).

It is necessary to change the behavior of individuals to improve the degree of health and reduce the pain of cervical cancer. Various theories can be used as a basis for behavioral change, one of them is Social Cognitive Theory (SCT). The SCT theory developed by Albert Bandura in 1986 states that individual experiences, other people's behavior, and environmental factors can influence someone's health behavior (Murti, 2018). This factor is based on interrelated three-way reciprocal models namely personal cognitive factors, environmental factors, and behavioral factors (Tougas et al., 2015).

Based on some of the theories above and the rarity of SCT theory research in the application of changes in health behavior, Authors are interested in conducting study on the determinants of VIA examination that is emphasized with SCT theory.

\section{SUBJECTS AND METHOD}

\section{Study Design}

This was an analytic observational study with a cross sectional design. The study was conducted at 25 community health centers in Magelang, Central Java, from September to October 2019.

\section{Population and Sample}

The population in this study were married women aged 30 to 50 years old. A total samples of 200 women was selected by stratified random sampling.

\section{Study Variables}

The dependent variable was VIA uptake. The independent variables were knowledge, observational learning, behavioral reinforcement, cues to action, access to information, family support, attitude, self-efficacy, outcome expectation, and contextual health center.

4. Operational Definition of Variables VIA uptake was an action taken as a form of early detection of cervical cancer by applying acetic acid to the cervix. The data were collected by questionnaire. The measurement scale was categorical.

Knowledge about cervical cancer was an understanding of study subjects about cervical cancer from the results of learning or information obtained. The data were collected by questionnaire. The measurement scale was continuous, but for data analysis, it was transformed into dichotomous.

Observational learning was an action taken by a woman because of the result of the process of observing and imitating the behavior of others, advertisements, or figures who become role models for her. The data were collected by questionnaire. The measurement scale was continuous, but for data analysis, it was transformed into dichotomous.

Behavior reinforcement was an effect that occurs after the study subject receives an award or punishment from the VIA examination. The data were collected by questionnaire. The measurement scale was continuous, but for data analysis, it was transformed into dichotomous.

Cues to action was an encouragement from the outside or from within that is obtained by 
women, causing women to conduct VIA uptake. The data were collected by questionnaire. The measurement scale was continuous, but for data analysis, it was transformed into dichotomous.

Information access was the degree of frequency and ease of study subjects in obtaining information about cervical cancer and early detection of VIA. The data were collected by questionnaire. The measurement scale was continuous and transformed into dichotomous.

Family Support was an encouragement in the form of positive support provided by family members in the study sub-section to con duct an IVA examination. The data were collected by questionnaire. The measurement scale was continuous and transformed into dichotomous.

Attitude was the belief, evaluation, and positive tendency of study subjects to act about everything related to early detection of cervical cancer. The data were collected by questionnaire. The measurement scale was continuous and transformed into dichotomous.

Self-efficacy was a perception and belief in the intention of study subjects that VIA examination is important to do. The data were collected by questionnaire. The measurement scale was continuous and transformed into dichotomous.

Outcome expectation was an assessment given by an individual regarding the importance of VIA examination. The data were collected by questionnaire. The measurement scale was continuous and transformed into dichotomous.

\section{Data Analysis}

Univariate analysis to describe in general each of the variables studied included VIA examination, knowledge, observational learning, behavioral reinforcement, cues to action, access to information, family support, attitudes, self-efficacy, and expected results. Bivariate analysis to explain the effect of one independent variable (knowledge, observational learning, behavioral reinforcement, cues to act, access to information, family support, attitudes, self-efficacy, and expected outcomes) on one dependent variable (IVA examination).

Multivariate analysis to explain the effect of more than one independent variable, namely the determinants of social cognitive theory on VIA examination behavior

\section{Research Ethic}

This study was conducted based on study ethics, namely informed consent, anonymity, confidentiality, and ethical eligibility. Ethics permission in this study was obtained from the Health Study Ethics Commission of Dr. Moewardi Hospital, Surakarta, Indonesia, No. 1026/VIII/HREC/2019.

\section{RESULTS}

\section{Sample Characteristics}

The sample characteristics described the continuous data of each study variable. The results of the analysis of continuous data sample descriptions were shown in table 1.

\section{Univariate analysis}

Table 2 showed a description of the results of study on each study variable. Most of the study subjects never did an VIA test were 145 women (72.5\%), have good knowledge about cervical cancer were 108 women (54\%), have little observational learning were 101 women (50.5\%), has strengthened weak behaviors were 122 women (61\%), have weak gestures to act were 121 women (6o.5\%), have poor access to information were 108 women (54\%), have low family support were 128 women (64\%), had a negative attitude were 127 women (63.5\%), had weak self-efficacy were 128 women (64\%), and had low expectations by 110 women $(55 \%)$. 
Martangingrum et al./ Contextual Effect of Community Health Center on Visual Inspection Acetic Acid

Table 1. Sample characteristics of continuous data

\begin{tabular}{lccccc}
\hline \multicolumn{1}{c}{ Variables } & n & Mean & SD & Min. & Max. \\
\hline Knowledge & 200 & 5.70 & 1.85 & 2 & 9 \\
Observational learning & 200 & 10.90 & 2.84 & 6 & 18 \\
Behavior reinforcement & 200 & 15.51 & 3.89 & 8 & 24 \\
Cues to action & 200 & 17.51 & 5.27 & 10 & 30 \\
Information access & 200 & 18.50 & 4.90 & 10 & 29 \\
Family support & 200 & 20.50 & 5.08 & 10 & 30 \\
Attitude & 200 & 19.53 & 4.12 & 12 & 27 \\
Self-efficacy & 200 & 20.08 & 5.63 & 10 & 30 \\
Outcome expectation & 200 & 16.21 & 2.96 & 11 & 21 \\
\hline
\end{tabular}

Table 2. Sample characteristics of categorical data

\begin{tabular}{llcc}
\hline Variables & Category & Frequency (n) & Percentage (\%) \\
\hline VIA uptake & No & 145 & 72.5 \\
& Yes & 55 & 27.5 \\
Knowledge & Poor $(<6)$ & 92 & 46.0 \\
& Good $(\geq 6)$ & 108 & 54.0 \\
Observational Learning & Low $(<11)$ & 101 & 50.5 \\
& High $(\geq 11)$ & 99 & 49.5 \\
Behavioral Reinforcement & Weak $(<16)$ & 122 & 61.0 \\
& Strong $(\geq 16)$ & 78 & 39.0 \\
Cues to Act & Weak $(<18)$ & 121 & 60.5 \\
Information Access & Strong $(\geq 18)$ & 79 & 39.5 \\
& Poor $(<19)$ & 108 & 54.0 \\
Family Support & Good $(\geq 19)$ & 92 & 46.0 \\
Attitude & Weak $(<21)$ & 128 & 64.0 \\
Self-Efficacy & Strong $(\geq 21)$ & 72 & 36.0 \\
Access to Information & Negative $(<20)$ & 127 & 63.5 \\
& Positive $(\geq 20)$ & 73 & 36.5 \\
& Weak $(<20)$ & 128 & 64.0 \\
& Strong $(\geq 20)$ & 72 & 36.0 \\
& Low $(<16)$ & 110 & 55.0 \\
\hline
\end{tabular}

\section{The result of bivariate analysis}

Bivariate analysis in this study used Chi Square analysis. Table 3 showed the test results of the influence of independent study variables on VIA test. Knowledge influenced the test of VIA. Women with good knowledge were 19.68 times more likely to have VIA examination ( $\mathrm{OR}=19.68$; $\mathrm{p}<0.001)$. Observational learning affected the VIA test. Women with observational learning (observing the behavior of others) were 4.3 times more likely to conduct VIA test $(\mathrm{OR}=4.3 ; \mathrm{p}<0.001)$.

Behavioral reinforcement affected the VIA test. Women with strong behavioral reinforcement were 41.78 times more likely to do
VIA test $(\mathrm{OR}=41.78 ; \mathrm{p}<0.001)$.

Cues to act affect the VIA test. Women with strong cues to act were 20.74 times more likely to have VIA test $(\mathrm{OR}=20.74 ; \mathrm{p}<0$. o01). Information access influenced the VIA test. Women with good information access were 19.37 times more likely to have VIA test $(\mathrm{OR}=19.37$; $\mathrm{p}<0.001)$. Family support influenced the VIA test. Women with strong family support were 19.66 times more likely to have VIA test $(\mathrm{OR}=19.66 ; \mathrm{p}<0.001)$. Attitude affected the VIA test. Women with a positive attitude were 22.33 times more likely to have VIA test $(\mathrm{OR}=22.33 ; \mathrm{p}<0.001)$. Self-efficacy affected the VIA test. Women with strong 
Martangingrum et al./ Contextual Effect of Community Health Center on Visual Inspection Acetic Acid

self-efficacy were 43.31 times more likely to conduct VIA test $(\mathrm{OR}=43.31 ; \mathrm{p}<0.001)$. The expected results affected the VIA test. Wo- men with high expectations for outcomes were 34.65 times more likely to conduct VIA test $(\mathrm{OR}=34.65 ; \mathrm{p}<0.001)$.

Table 3. Chi Square test on the factors influencing VIA uptake

\begin{tabular}{|c|c|c|c|c|c|c|}
\hline \multirow{2}{*}{ Independent Variables } & \multicolumn{2}{|c|}{ Non VIA } & \multicolumn{2}{|c|}{ VIA } & \multirow[b]{2}{*}{ OR } & \multirow[b]{2}{*}{$\mathbf{p}$} \\
\hline & $\mathbf{n}$ & $\%$ & $\mathbf{n}$ & $\%$ & & \\
\hline \multicolumn{7}{|l|}{ Knowledge } \\
\hline Poor $(<6)$ & 88 & 95.65 & 4 & 4.35 & \multirow[t]{3}{*}{19.68} & \multirow[t]{2}{*}{$<0.001$} \\
\hline Good $(\geq 6)$ & 57 & 52.78 & 51 & 47.22 & & \\
\hline \multicolumn{6}{|l|}{ Observational Learning } & \\
\hline Low $(<11)$ & 87 & 86.14 & 14 & 13.86 & \multirow{3}{*}{$4 \cdot 30$} & \multirow[t]{2}{*}{$<0.001$} \\
\hline $\operatorname{High}(\geq 11)$ & 58 & 58.59 & 41 & 41.41 & & \\
\hline \multicolumn{6}{|c|}{ Behavioral Reinforcement } & \\
\hline Weak $(<16)$ & 117 & 95.90 & 5 & 4.10 & \multirow[t]{3}{*}{41.78} & \multirow[t]{2}{*}{$<0.001$} \\
\hline Strong $(\geq 16)$ & 28 & 35.90 & 50 & 64.10 & & \\
\hline \multicolumn{6}{|l|}{ Cues to Act } & \\
\hline Weak $(<18)$ & 113 & $93 \cdot 39$ & 8 & 6.61 & \multirow[t]{3}{*}{20.74} & \multirow[t]{2}{*}{$<0.001$} \\
\hline Strong $(\geq 18)$ & 32 & 40.51 & 47 & 59.49 & & \\
\hline \multicolumn{6}{|l|}{ Access to Information } & \\
\hline Poor $(<19)$ & 102 & 94.44 & 6 & 5.56 & \multirow[t]{2}{*}{19.37} & \multirow[t]{2}{*}{$<0.001$} \\
\hline Good $(\geq 19)$ & 42 & 46.74 & 49 & 53.26 & & \\
\hline \multicolumn{7}{|l|}{ Family Support } \\
\hline Weak $(<21)$ & 118 & 92.19 & 10 & 7.81 & \multirow[t]{3}{*}{19.66} & \multirow[t]{2}{*}{$<0.001$} \\
\hline Strong $(\geq 21)$ & 27 & $37 \cdot 50$ & 45 & 62.50 & & \\
\hline \multicolumn{6}{|l|}{ Attitude } & \\
\hline Negative $(<20)$ & 118 & 92.91 & 9 & 7.09 & \multirow[t]{3}{*}{22.33} & \multirow[t]{2}{*}{$<0.001$} \\
\hline Positive ( $\geq 20$ ) & 27 & 36.99 & 46 & 63.01 & & \\
\hline \multicolumn{6}{|l|}{ Self-Efficacy } & \\
\hline Weak $(<20)$ & 122 & $95 \cdot 31$ & 6 & 4.69 & \multirow[t]{3}{*}{$43 \cdot 31$} & \multirow[t]{2}{*}{$<0.001$} \\
\hline Strong $(\geq 20)$ & 23 & 31.94 & 49 & 68.06 & & \\
\hline \multicolumn{6}{|l|}{ Expected Result } & \\
\hline Low $(<16)$ & 106 & 96.36 & 4 & 3.64 & \multirow[t]{2}{*}{34.65} & $<0.001$ \\
\hline $\operatorname{High}(\geq 16)$ & 39 & $43 \cdot 33$ & 51 & 56.67 & & \\
\hline
\end{tabular}

\section{The result of multivariate}

Multivariate analysis used multilevel multiple logistic regression methods by using the Stata 13 program. Table 4 showed that VIA test would increase with good knowledge $(\mathrm{b}=$ 4.02; $95 \% \mathrm{CI}=0.61$ to $7.42 ; \mathrm{p}=0.021$ ), more observational learning $(b=2.28 ; 95 \% \mathrm{CI}=-$ 0.35 to $4.93 ; \mathrm{p}=0.090$ ), strong behavior reinforcement $(\mathrm{b}=4.11 ; 95 \% \mathrm{CI}=0.82$ to 7.40 ; $\mathrm{p}=0.014)$, strong cues to action $(b=5.36$;
95\% $\mathrm{CI}=0.65$ to $10.07 ; \mathrm{p}=0.026)$, good access to information $(b=3.71 ; 95 \% \mathrm{CI}=0.42$ to $7.01 ; \mathrm{p}=0.027$ ), strong family support $(\mathrm{b}=$ 4.23 ; $95 \% \mathrm{CI}=0.21$ to $8.25 ; \mathrm{p}=0.039$ ), positive attitude $(b=3.29 ; 95 \% \mathrm{CI}=-0.23$ to 6.81 ; $\mathrm{p}=0.067)$, strong self-efficacy $(\mathrm{b}=2.94 ; 95 \%$ $\mathrm{CI}=0.10$ to $5.78 ; \mathrm{p}=0.042$ ), and high expected result $(b=3.39 ; 95 \% \mathrm{CI}=0.35$ to $6.44 ; \mathrm{p}=$ o.029). Health centers had strong contextual effect on VIA uptake (ICC $=23 \%)$. 
Martangingrum et al./ Contextual Effect of Community Health Center on Visual Inspection Acetic Acid

Table 4. The result of multilevel multiple logistic regression on the factors associated with VIA uptake

\begin{tabular}{|c|c|c|c|c|}
\hline \multirow{2}{*}{ Independent Variables } & \multirow{2}{*}{$\mathbf{b}$} & \multicolumn{2}{|c|}{ 95\% CI } & \multirow[b]{2}{*}{$\mathbf{p}$} \\
\hline & & Lower Limit & Upper Limit & \\
\hline \multicolumn{5}{|l|}{ Fixed Effect } \\
\hline Knowledge (good) & 4.02 & 0.61 & 7.42 & 0.021 \\
\hline Observational learning (more) & 2.28 & -0.35 & 4.93 & 0.090 \\
\hline Behavioral reinforcement (strong) & 4.11 & 0.82 & 7.40 & 0.014 \\
\hline Cues to act (strong) & $5 \cdot 36$ & 0.65 & 10.07 & 0.026 \\
\hline Information access (good) & 3.71 & 0.42 & 7.01 & 0.027 \\
\hline Family support (strong) & 4.23 & 0.21 & 8.25 & 0.039 \\
\hline Attitude (positive) & 3.29 & -0.23 & 6.81 & 0.067 \\
\hline Self-efficacy (strong) & 2.94 & 0.10 & 5.78 & 0.042 \\
\hline Expected result (high) & 3.39 & 0.35 & 6.44 & 0.029 \\
\hline \multicolumn{5}{|l|}{ Random Effect } \\
\hline Health center var (constants) & 0.99 & 0.35 & 6.44 & \\
\hline \multicolumn{5}{|l|}{$\mathrm{N}$ Observation $=200$} \\
\hline \multicolumn{5}{|l|}{$\mathrm{N}$ health center $=25$} \\
\hline \multicolumn{5}{|l|}{ Log likelihood $=-17.79$} \\
\hline $\mathrm{ICC}=23 \%$ & & & & \\
\hline
\end{tabular}

\section{DISCUSSION}

\section{The effect of knowledge on VIA up-} take

The results of this study indicated that knowledge has an influence on VIA test. Knowledge about cervical cancer screening in women who have had a VIA examination was different from women who have never had VIA examination (Orang'O et al., 2016). Good knowledge of cervical cancer enhanced women's behavior to carry out cancer screening (Ashtarian et al., 2017).

Lack of women's behavior in seeking health services, lack of information, and lack of initiative to find information themselves were factors that cause women to have low knowledge (Aweke et al., 2017). Efforts to increase knowledge were needed as a preventative measure (Tefera and Mitiku, 2016).

\section{The effect of observational learning} on VIA uptake

The results of this study indicated that observational learning has an influence on VIA test. This supported the theory postulated by Bandura regarding social cognitive theory that when an individual observes a behavior and feels good, then he will use that infor- mation to behave on himself (Murti, 2018).

Peer support was very influential on VIA examination (Sahr et al., 2018). This support can be in the form of providing information, providing examples of behavior, and emotional support (Taylor, 2011). Examples of behavior and invitations from friends were enough to influence a woman's decision to conduct VIA test because she felt confident with the story and invitation from her friend (Murti, 2018).

Peer support was very influential on VIA test (Sahr et al., 2018). This support can be in the form of providing information, providing examples of behavior, and emotional support (Taylor, 2011). Examples of behavior and invitations from friends enough to influence a woman's decision to do VIA test because she felt confident with the stories and invitations from friends (Parapat et al., 2016).

The support of health personnel also contributed to the observational learning process. Women with the support of high health personnel were more likely to have VIA test (Wakhidah et al., 2017). The public adhered to the mindset in themselves that he- 
alth personnels were role models in health behavior (Tejoyuwono, 2018). Role models have a strong impact on women's decisions about health care (Kim et al., 2012).

\section{The effect of behavioral reinforce- ment on VIA uptake}

The results of this study indicated that behavioral reinforcement has an effect on VIA test. Giving rewards or punishment can improve a person in performing health behaviors (Putri and Martiana, 2018). Some aspects included in the behavioral reinforcement factors were social support, doctor/patient relationships, and peer influence. This reinforcing factor would have a significant effect on screening behavior (Hatcher et al., 2011).

In addition, there are inhibiting factors in behaving. The perceived obstacle was a potential negative consequence to reduce the desire to behave. Common obstacles were feelings of fear, shame, fear of being contrary to religious principles (Sahr and Kusumaningrum, 2018).

\section{The effect of cues to act on VIA up- take}

The results of this study indicated that cues to act have an effect on VIA test. Cues to act can came from internal factors (signs or symptoms of health complaints) and external factors (information from relatives, media, and health personnel's) (Setiyaningsih et al., 2016).

Women who have a high cue to act were more likely to conduct VIA test (Sunarta et al., 2019). The cues act were influenced by the proper perception of cervical cancer and VIA test (Were et al., 2011).

Previous qualitative study showed that the way women look at early detection of cervical cancer was very influential with a woman's decision to conduct an early detection of cervical cancer. Some women argued that screening was related to cancer and death. This made women avoid and were reluctant to do VIA test. But for women who have a good perception of cervical cancer screening, they actually viewed that the test was very important to prevent death (Rasul et al., 2015).

\section{The effect of access to information on VIA uptake}

The results of this study indicated that access to information has an influence on VIA test. Access to information can influence the behavior of VIA test, including the participation or presence of women in socialization activities about VIA test (Junainah, 2017).

The more often and many terms of cervical cancer screening obtained by a person, then she would easily decide to behave in a healthy and cervical cancer screening (Wood et al., 2018).

Women who have previously heard and obtained information about cervical cancer screening or VIA test were more likely to conduct VIA test (Chosamata el al., 2015).

\section{The effect of family support on VIA uptake}

The results of this study indicated that family support has an effect on VIA test behavior. Most women who conduct VIA test got strong support from their husbands (Chigbu et al., 2013).

Social support from others, including families, provided benefits for individuals who receive it because they felt cared for, valued, and loved (Harnilawati, 2013).

Women who have discussed with their husbands or families about cervical cancer screening were more likely to have the intention and drive to conduct an early detection examination (Black et al., 2019).

\section{The effect of attitude on VIA uptake}

The results showed that attitude had an influence on VIA test behavior. Women with a negative attitude towards VIA examination have a smaller likelihood of being screened compared to those who have a positive attitude (Idowu et al., 2016). 
A positive attitude was a form of anticipation and belief that screening was a step in preventing the development of cervical cancer (Bante et al., 2019). A good attitude towards health would have an impact on good health behavior (Hamzah et al, 2019). The attitude that someone has referred to the extent to which the individual evaluated both positive and negative oneself towards the behavior she/he wanted to do (Aboidun et al., 2014).

\section{The effect of self-efficacy on VIA up- take}

The results of the study were in accordance with the constructs of social cognitive theory that self-efficacy affected someone's behavior (Murti, 2018).

Someone's self-efficacy can be used to predict healthy behavior and facilitate behavioral change efforts (Onoruoiza et al., 2015). Women with strong self-efficacy were more likely to have cervical cancer screening than women with weak self-efficacy (Armadhani el al., 2019). Self-efficacy owned by someone can change along with her/his development. The more a woman has a good knowledge of cervical cancer screening, the higher the efficacy of cervical cancer screening (Tiraki and Yllmaz, 2017).

\section{The effect of expected result on VIA uptake}

The results of this study indicated that the expectations of the results have an effect on the behavior of VIA test. The expected results need to be known to assess whether the behavior can improve the degree of health, or even cause pain as a form of anticipation (Murti, 2018).

Generally, most women feel afraid to accept the results of VIA examination (Hassan et al., 2018), but some women also realized that cervical cancer screening was very necessary and important in the future (MacLaughlin et al., 2011).

\section{The contextual effect of health cen- ter on VIA uptake}

Health center has a significant and contextual influence on VIA test behavior in women with ICC of $23 \%$. This mean that $23 \%$ of the variation in VIA test behavior was influenced by factors at the health center level.

Health center was a health service facility that organized health efforts by prioritizing promotive and preventive efforts, to achieve the highest degree of public health (Minis ter of Health, 2014).

The provision of cervical cancer prevention services to women carried out must place the perspective of accessibility, availability, affordability, acceptance, and quality of service as important because it can affect the coverage of women to conduct cervical cancer screening (Nwobodo et al., 2015).

Public perceptions about the importance of health must also be increased because the public's perception of health highly influenced the utilization of health services (Napirah et al., 2016). The support of health personnel contributed to efforts to increase women's awareness to conduct VIA tests. The main role of health personnel here was to provide knowledge about cervical cancer and the importance of early detection, and provide motivation for women to do early detection of cervical cancer (Nisa et al., 2019).

The reality was that the health care system of the health center was different from one another. This was partly due to the stratification of health center accreditation and the competencies of the health personnel's in it. It was possible for an accredited health center to have expertise so that it can create an innovation program to increase coverage and actively make pro-motive efforts to the community (Lubis et al., 2016).

VIA uptake increases with good knowledge, observational learning, strong behavio 
ral reinforcement, strong cues to action, good access to information, strong family support, positive attitude, strong self-efficacy, and strong outcome expectation. Community health center has strong contextual effect on VIA uptake.

\section{AUTHOR CONTRIBUTION}

Herlina Ika Martaningrum as the main author, the roles were to carry out the study, collect study data, and compile study articles. Uki Retno Budihastuti provided input in the study discussion. Bhisma Murti played a role in the process of data analysis and interpretation of study results.

\section{CONFLICT OF INTEREST}

We declare that we do not have any conflict of interest.

\section{FUNDING AND SPONSORSHIP}

This study used personal funds from the main author.

\section{ACKNOWLEDGEMENT}

The author would like to say thank you to 25 heads of health center in Magelang, Central Java, who allowed this study to be carried out and to all study subjects who were willing and cooperative to be part of this study.

\section{REFERENCE}

Abiodun OA, Olu-Abiodun OO, Sotunsa JO, Oluwole FA (2014). Impact of health education intervention on knowledge and perception of cervical cancer and cervical screening uptake among adult women in rural communities in $\mathrm{Ni}$ geria. BMC Public Health, 14(814), 1-9. https://doi.org/10.1186/147-2458-14814

Armadhani R, Mudigdo A, Budihastuti UR (2019). Path Analysis on the determinants of PAP smear uptake in women of reproductive age in Tegal, Central Java. J Matern Child Health. 4(2): 77-
86. https://doi.org/10.26911/thejmch.2019.04.02.03

Ashtarian H, Mirzabeigi E, Mahmoodi E, Khezeli M (2017). Knowledge about cervical cancer and PAP smear and the factors influencing the pap test screening among women. Int $\mathrm{J}$ Community Based Nurs Midwifery. 5(2): 188-195. Retrieved from https://www.ncbi.nlm. nih.gov/pmc/articles/PMC5385241/.

Aweke YH, Ayanto SY, Ersado TL (2017). Knowledge, attitude and practice for cervical cancer prevention and control among women of childbearing age in Hossana Town, Hadiya zone, Southern Ethiopia: community-based cross sectional study. PLoS ONE. 12(7): 1-18. https://doi.org/10.1371/journal.pone.o 181415

Bante SA, Getie SA, Getu AA, Mulatu K, Fenta SL (2019). Uptake of pre-cervical cancer screening and associated factors among reproductive age women in Debre Markos town, Northwest Ethio pia, 2017. BMC Public Health. 19(1): 19. https://doi.org/10.1186/s12889-0197398-5

Black E, Hyslop F, Richmond R (2019). Barriers and facilitators to uptake of cer vical cancer screening among women in Uganda: a systematic review. BMC Women's Health. 19(108): 1-12. https: //doi.org/10.1186/s12905-01908 09-z

Central Java Health office (2018). The health profile of the province of Central Java in 2017. Semarang: Dinkes Jateng. Retrieved from https://www.depkes. go.id /profil_13_Jateng_2017

Chigbu CO, Onyebuchi AK, Ajah LO, Onwudiwe EN (2013). Motivations and preferences of rural Nigerian women undergoing cervical cancer screening via visual inspection with acetic acid. Int $\mathrm{J}$ Gynaecol Obstet. 120(3): 262-265. http s://doi.org/10.1016/j.ijgo.2012.10.011 
Martangingrum et al./ Contextual Effect of Community Health Center on Visual Inspection Acetic Acid

Chosamata MS, Hong SA, Tiraphat S (2015). Determinants of cervical cancer screening utilization among women aged 3045 years in Blantyre district, Malawi. Journal of Public Health and Development. 13(3): 19-34. Retrieved from https://www.tcithaijo.org/index.php/A IHD-MU/article/view/37669

Hamzah SR, Suandi T, Ismail M, Muda Z (2019). Association of the personal factors of culture, attitude and motivation with health behavior among adolescents in Malaysia. International Journal of Adolescence and Youth. 24(2): 149-159. https://doi.org/10.1080/o2673843.2018.1482772

Harnilawati (2013). The concept and process of family nursing. Sulawesi Selatan: Pustaka As Salam.

Hassan RB, Armawan E, Arya IFD (2018). Visual inspection test with acetic acid for cervical cancer screening: willingness and acceptability among reproductive age and married women. Althea Med J. 5(2): 98-104. https://doi.org /10.15850/amj.v5n2.1419

Hatcher J, Studts CR, Dignan M, Turner LM, Schoenberg NE (2011). Predictors of cervical cancer screening for rarely or never screened rural Appalachian women. J Health Care Poor Underserved. 22(1): 176-193. https://doi.org/10.1353 /h pu.2011.0021

Idowu A, Olowookere SA, Fagbemi AT, Ogunlaja OA (2016). Determinants of cervical cancer screening uptake among women in Ilorin, North Central Nigeria: a community-based study. J Cancer Epidemiol. 1-8. https://doi.org/10.11 $55 / 2016 / 6469240$

Junainah N (2017). Inclusion of socialization and economic level to the participation of visual inspection of acetic acid. Higeia Journal of Public Health Research and Development. 1(3): 129-
139. Retrieved from http://journal. unnes.ac.id/sju/index.php/higeia/artcl e/view/15982

Kim YM, Ati A, Kols A, Lambe FM, Soetikno D, Wysong M, Tergas AI, Rajbhandari $\mathrm{P}, \mathrm{Lu} \mathrm{E}$ (2012). Influencing women's actions on cervical cancer screening and treatment in Karawang district, Indonesia. Asian Pac J Cancer Prev. 13(6): 2913-2921. https://doi.org/10. 7314/APJCP.2012.13.6.2913

Lubis Z, Muda S, Rasmaliah (2016). Analysis of the relationship between supporting and reinforcing predisposing factors with the participation of mothers of childbearing age for IVA testing in the working area of Helvetia Health Center, Medan Helvetia District in 2016. Gizi, Kesehatan Reproduksi Dan Epidemiologi. 1(3): 1-12. Retrieved from https://jurnal.usu.ac.id/index.php/gkr e/article/view/15486/8981

MacLaughlin KL, Angstman KB, Flynn PM, Schmit JR, Weaver AL, Shuster LT (2011). Predictors of patient comfort and adherence with less frequent cervical cancer screening. Quality in Primary Care. 19(6): 355-363. Retrieved from https://www.ncbi.nlm.nih.gov/pubmed/22340898

Magelang Regency Health Office (2018). Data for early detection of cervical cancer and breast cancer according to community health center in 2018. Retrieved from http://dinkes.magelangkab.go.id/

Ministry of Health (2019). World's cancer day. Retrieved from http://www.depkes.go.id/article/view/19020100003/h ari-kan-ker-sedunia-2019.html

Ministry of Health (2014). Regulation of the Minister of Health of the Republic of Indonesia No 75 of 2014 concerning community health centers. Jakarta: Kemenkes RI. Retrieved from http://aspak.yankes.kemkes.go.id/beranda/do 
Martangingrum et al./ Contextual Effect of Community Health Center on Visual Inspection Acetic Acid

wnload/PMK-No.-75-ttg-Puskesmas.pdf

Momenimovahed Z, Salehiniya H (2017). Incidence, mortality and risk factors of cervical cancer in the world. Biomedical Research and Therapy. 4(12): 17951811. https://doi.org/10.15419/bmrat.v $4 \mathrm{i} 12.386$

Murti B (2018). Promotion theory and health behavior. Surakarta: Program Studi Ilmu Kesehatan Masyarakat

Napirah MR, Rahman A, Tony A (2016). Factors related to the utilization of health services in the working area of Tambarana Health Center, Poso Pesisir Utara District, Poso Regency. Jurnal Pengembangan Kota. 4(1): 29-39. https://doi.org/10.14710/jpk.4.1.29-39.

Nisa W, Ginting R, Girsang E (2019). Factors that influence the use of visual inspection of acetic acid (VIA) in women of reproductive age in the working area of Mandala Health Center, Medan Tembung District, Medan City. Jurnal Kesehatan Global. 2(2): 71-80. Retrieved from https://ejournal.helv-etia.ac.id/index.php/jkg

Nwobodo H, Ba-Break M (2015). Analysis of the determinants of low cervical cancer screening uptake among Nigerian women. J Public Health Afr. 6(484): 1219. https://doi.org/10.4081/jphia.2015.484

Onoruoiza SI, Musa A, Umar BD, Kunle YS (2015). Using health beliefs model as an intervention to non-compliance with hypertension information among hypertensive patient. IOSR Journal of Humanities and Social Science. 20(9): 11-16. https://doi.org/10.9790/o83720951116

Orang'O EO, Wachira J, Asirwa FC, Busakhala N, Naanyu V, Kisuya J, Otieno G, Keter A, Mwangi A, Inul T (2016). Factors associated with uptake of visual in- spection with acetic acid (VIA) for cervical cancer screening in Western Kenya. PLoS ONE. 11(6): 1-12. https://doi.org/10.1371/journal.pone.0157217

Parapat FT, Setyawan H (2016). Factors related to early detection of cervical cancer behavioral methods of visual inspection of acetic acid in Candiroto Health Center, Temanggung Regency. Jurnal Kesehatan Masyarakat. 4(4): 363-370. Retrieved from https://ejournal3.un dip.ac.id/index.php/jkm/article/view/141 50

Putri RW, Martiana T (2018). The relationship of reward and punishment with the behavior of the work personnel's in carrying out the stop program. The Indones J Occupational Safety Health. 7(2): 172-180. https://doi.org/10.20473/ijosh.v7i2.2018

Rasul VH, Cheraghi MA, Behboodi MZ (2015). Influencing factors on cervical cancer screening from the Kurdish women's perspective: a qualitative study. Journal of Medicine and Life. 8(2): 4754. Retrieved from www.ncbi.nlm.nih.gov/pmc/articles/PMC5327709/

Sahr LA, Kusumaningrum TAI (2018). Perception and behavior of women of reproductive age in conducting visual inspection tests of acetic acid. Jurnal Promosi Kesehatan Indonesia. 13(2): 114128. https://doi.org/10.14710/jpki.13.2. 114-128

Setiyaningsih R, Tamtomo D, Suryani N (2016). Health belief model: determinants of hypertension prevention behavior adults at community health center, Sukoharjo, Central Java. J Health Promot Behav. 1(3): 161-171. https://doi.org/10.26911/thejhpb.2016.01.03 .03

Shaheen, Sharma R, Rashi (2014). Visual inspection with acetic acid (VIA) in cervi- 
Martangingrum et al./ Contextual Effect of Community Health Center on Visual Inspection Acetic Acid

cal cancer screening in low resource set tings. Bangladesh J Med. 13(4): 454459. https://doi.org/10.3329/bjms.v13i4.15019.

Sunarta EA, Sulaeman ES, Budihastuti UR (2019). Path analysis on the determinants of visual inspection acetic acid utilization on early detection of cervical cancer: application of health belief model theory. J Health Promot Behav. 4(1): 32-42. https://doi.org/10.26911/thejhpb.2019.04.01.04

Taylor S (2011). Social support: Oxford book of health psychology. New York: Oxford University Press.

Tefera F, Mitiku I (2016). Uptake of cervical cancer screening and associated factors among 15-49 yearold women in Dessie town, Northeast Ethiophia. J Cancer Educ. 1-7. https://doi.org/10.1007/s13 187-016-1021-6

Tejoyuwono AAT (2018). Health personnel as an example of healthy living behavior in society: qualitative research. Berita Kedokteran Masyarakat. 34 (11). https://doi.org/10.22146/bkm.40537

Tiraki Z, Yilmaz M (2017). Cervical cancer knowledge, self-efficacy, and helth literacy levels of married wowan. J Cancer Educ. 1-10. https://doi.org/10.1007/s13187-017-1242-3

Tougas ME, Hayden JA, McGrath PJ, Huguet A, Rozario S (2015). A systematic review exploring the social cognitive theory of self-regulating as a framework for chronic health condition intervention. PLoS ONE. 10(8): 1-19. https:- //doi.org/10.1371/journal.pone.013497 7

Wakhidah MS, Hastuti URB, Dewi YLR (2017). The influence of personal factor, husband's support, health workers and peers toward the use of iva screening among women of reproductive age in the regency of Karanganyar. $\mathrm{J}$ Health Promot Behav. 2(2): 124-137. https://doi.org/10.26911/thejhpb.2017.02.02.03

Were E, Nyaberi Z, Buziba N (2011). Perceptions of risk and barriers to cervical cancer screening at moi teaching and referral hospital, Eldoret, Kenya. Afr Health Sci. 11(1): 58-64. Retrieved from https://www.ncbi.nlm.nih.gov/pubmed/21572858Abiodun OA, OluAbiodun OO, Sotunsa JO, Oluwole FA (2014). Impact of health education intervention on knowledge and perception of cervical cancer and cervical screening uptake among adult women in rural communities in Nigeria. BMC Public Health, 14(814), 1-9. https://doi.org/10.1186/147-2458-14-814

WHO (2018). Cancer. Retrieved from https://wwww.who.int/newsroom/factsheets /detail/cancer

Wood B, Rusell VL, El-Khatib Z, McFaul S, Taljaard M, Little J, Graham ID (2018). They should be asking us: a qualitative decisional needs assessment for women considering cervical cancer screening. Global Qualitative Nursing Research. 5: 1-14. https://doi.org/10.1177/2333393 618783632 